\title{
Effects of monocular deprivation on the thickness of neural retina
}

\author{
MWACHAKA, P. * SAIDI, H., ODULA, P. and MANDELA, P. \\ Department of Human Anatomy, University of Nairobi, 00100-30197, Nairobi, Kenya \\ *E-mail: pmaseghe@gmail.com
}

\begin{abstract}
Background: Monocular visual deprivation as a result of cataracts occurring in children who previously had normal vision may result in permanent visual deficits. However, if correction is done before the age of ten years, vision is usually restored to normal levels in the affected eye. This has been attributed to plastic changes that occur in the visual cortex, with no mention of the contribution of the retina to this plasticity. Objective: To describe the effect of monocular deprivation on the thickness of neural retina. Study design: Quasi-experimental study using a rabbit model. Materials and methods: 30 rabbits (18 experimental, 12 controls) were examined. Monocular deprivation was achieved through unilateral lid suture in the experimental animals. The rabbits were observed for three weeks. Each week, 6 experimental and 3 control animals were euthanized, their retina harvested and processed for light microscopy. In experimental animals, retina of both deprived (closed) and non-deprived (open) eyes were studied. Haematoxylin \& Eosin stain was used to demonstrate the layers of the retina. Photomicrographs of the retina were taken using a digital camera then entered into FIJI software for analysis. Results: In the deprived eyes, the neural retina thickness reduced by $40.5 \%$ from the baseline $(\mathrm{p}=0.001)$. Compared to controls, statistically significant reduction in thickness was noted in the ganglion $(\mathrm{p}<0.001)$, inner nuclear $(\mathrm{p}<0.001)$, rod and cones $(\mathrm{p}=0.001)$, outer plexiform $(\mathrm{p}=0.008)$, nerve fiber $(\mathrm{p}=0.010)$, and inner plexiform $(\mathrm{p}=0.024)$ layers. Among the non-deprived eyes, the neural retina thickness increased by $9.8 \%$ from baseline $(\mathrm{p}=0.075)$. Compared to controls, statistically significant increase in thickness was seen in the inner plexiform $(\mathrm{p}<0.001)$, inner nuclear $(\mathrm{p}=0.002)$, and rods and cones $(\mathrm{p}=0.007)$ layers. Conclusion: Monocular deprivation results in atrophy of the retina in the deprived eye. Thus, pre-retinal causes of blindness such as cataracts affects the retina and should be corrected early so as to minimize damage to the retina of the deprived eye.
\end{abstract}

Keywords: neural retina, monocular deprivation, rabbit model.

\section{Introduction}

The retina plays a critical role in visual perception as it contains the initial components of the visual pathway (MASLAND, 2011). The retina develops from out-pouchings of the neural tube known as optic vesicles (MOORE, PERSAUD and TORCHIA, 2013), and is morphologically made up of an outer retinal pigment epithelium and inner neural retina. The neural retina is the photosensitive layer, and contains several cell types namely photoreceptors (rods and cones), conducting neurons (bipolar and retinal ganglion cells), interneurons (horizontal, and amacrine cells), and glial cells MASLAND, 2012). These cells are arranged in three histologically distinct "nuclear" layers that contain cell bodies but no synapses, separated by two "plexiform" layers that contain synapses but no cell bodies (MASLAND, 2012). Axons of ganglion neurons form the optic nerve that synapses with third order neurons at the lateral geniculate body of the thalamus (KOLB, FERNANDEZ, NELSON, 1995). The third order neurons mainly project to the primary visual cortex where processing of the visual information takes place (MASLAND, 2012).

Visual deprivation by lid suture has been used as a reliable laboratory model for studying anatomical and electrophysiological changes in the visual cortex resulting from visual impairments such as cataracts (DEWS and WIESEL, 1970). According to World Health Organization report, cataract is the leading cause of visual impairment, accounting for $50 \%$ of blindness in Sub Saharan Africa (WORLD..., 2012). Monocular visual deprivation as a result of cataracts occurring in children who previously had normal vision results in permanent visual deficits if the cataracts are not corrected early (LEWIS and MAURER, 2005). However if correction is done early, before the age of ten years, visual acuity is usually restored to normal levels in the affected eye (VAEGAN and TAYLOR, 1979; ELLEMBERG, LEWIS, MAURER et al., 2000; LEWIS and MAURER, 2005). These observations have been attributed to the plastic changes in the visual cortex (ELLEMBERG, LEWIS, MAURER et al., 2000; LEWIS and MAURER, 2005). Studies on monocularly deprived animals have demonstrated the visual cortex undergoes anatomical changes in favor of the non-deprived eye such as increase in cortical thickness, neuronal cell density, and synaptic contacts (HOFER, MRSIC-FLOGEL, BONHOEFFER et al., 2006; LEHMANN and LÖWEL, 2008). Although the retina is considered as part of the nervous system based on its embryonic development and its cellular content, there is scarcity of information on the structural changes occurring in the retina as a result of monocular deprivation.

Several animal models such as the mice, monkeys, rabbits, tree shrews, and cats have been used in vision research (DEWS and WIESEL, 1970; AMTHOR, TAKAHASHI and OYSTER, 
1989; BARO, LEHMKUHLE and KRATZ, 1990; MACNEIL, HEUSSY, DACHEUX et al., 2004; LEHMANN and LÖWEL, 2008; ABBOTT, GRÜNERT, PIANTA et al., 2011). Rabbits offer a good model for vision research because they are readily available, easier to handle, and their visual capabilities as well as the cell types of its retina have been studied in detail and characterized in a fashion similar to those in humans (AMTHOR, TAKAHASHI and OYSTER, 1989; STRETTOI, DACHEUX and RAVIOLA, 1994; MCGILLEM and DACHEUX, 2001; MACNEIL, HEUSSY, DACHEUX et al., 2004; MURAOKA, IKEDA, NAKANO et al., 2012). This study therefore aimed at describing the structural changes in the retina following monocular deprivation using a rabbit model.

\section{Materials and methods}

Study design: Non-randomized trial (Quasi experiment).

\subsection{Materials}

Thirty Californian White (oryctolagus cuniculus) rabbits were used. These rabbits were obtained from a local private commercial farm. The sample size was obtained using the following formula (SAKPAL, 2010; SURESH and CHANDRASHEKARA, 2012);

$n=\frac{(r+1)\left(z_{(\alpha / 2)}+z_{(1-\beta)}\right)^{2} \sigma^{2}}{r \delta^{2}}$

Where: $\mathrm{n}=$ sample size, $\mathrm{Z}_{(1-\beta)}=$ desired power (typically 0.84 for $80 \%$ power $), Z_{(\alpha / 2)}=$ desired level of statistical significance (typically 1.96 for a significance of 0.05 ), $\sigma=$ standard deviation, $\delta=$ smallest meaningful difference, $\mathrm{r}=\mathrm{nl} / \mathrm{n} 2$ is the ratio of sample size required for 2 groups (typically 1 for equal sample size for 2 groups. If $r=0.5$ gives the sample size distribution as 1:2 for 2 groups). A previous study by Muraoka, Ikeda, Nakano et al. (2012) had revealed that the total retinal thickness of a rabbit was $194.3 \pm 7.7 \mu \mathrm{m}$. Using a statistical significance of 0.05 , power of $80 \%$, and of $7.7 \mu \mathrm{m}$ (one standard deviation), and $r=0.5$ (ratio of controls to experimental animals of $1: 2$ ), the sample size was calculated as follows:

$n=\frac{(0.5+1)[1.96+0.84]^{2} * 7.7^{2}}{0.5^{*} 7.7^{2}}=$

$\frac{1.5^{*} 7.84}{0.5}=23.52=24$ animals

The sample size was increased to 30 animals to cater for a $25 \%$ drop out rate.

\subsection{Inclusion criteria}

Since the peak period for development of ocular dominance plasticity is between the $2 \mathrm{nd}$ and 4 th postnatal week, the rabbits were recruited into the study on their 14th postnatal day.

Exclusion criteria

Rabbits with obvious congenital or acquired eye disorders were excluded from this study.

\subsection{Ethical considerations}

The approval to carry out the study was granted by the Biosafety, Animal Care and Use Committee of the Faculty of Veterinary Medicine, University of Nairobi-Kenya.

\subsection{Handling of study animals}

The rabbits were kept in wire cages measuring 4 feet by 4 feet, floored with saw dust. Each cage housed one doe and its litter, and contained a nest box where the litter stayed. Since a nursing female and its litter require a minimum floor space of 7.5 square feet (for a doe more than $5 \mathrm{~kg}$ body weight), and one doe would have 6-12 kits per litter (average 8), then a 16 square foot cage would be spacious enough for each doe and its kits. The rabbits were fed on commercial rabbit pellets, half a cup of pellets per 5 kilogram body weight daily, and were offered water ad libitum through sipper bottles with nozzles. The rabbit cages were also cleaned daily.

\subsection{Monocular deprivation}

Eighteen rabbits (experimental animals) were recruited on their 14th post natal day. These rabbits were then clustered into two groups each containing eight rabbits. One group had their right eye lids sutured together while the other group had their left eye lids stitched up. These animals were restrained for body weight estimation and administration of medications using a restrain box, then anesthetized with intramuscular ketamine $(50 \mathrm{mg} / \mathrm{kg})$ and also given intramuscular analgesic (Flunixin meglumine $1.1 \mathrm{mg} / \mathrm{kg}$ ). Two drops of gentamycin (antibiotic) eye drops were applied on the eye to be deprived. The margins of the upper and lower lids of one eye were trimmed and sutured together using Nylon 5.0 single vertical mattress stitch in aseptic technique.

Following tarsorrhaphy, the rabbits were returned to their home cages and observed daily for suture breakdown or infection. Post-operative pain was managed by intramuscular Flunixin meglumine ( $1.1 \mathrm{mg} / \mathrm{kg}$ ) every 24 hours for 4 days. In addition, the animals were clinically assessed for signs and symptoms of pain such as poor feeding, facing the back of the cage (hiding posture), vocalization by means of a piercing squeal, kicking and scratching, and teeth grinding. Rabbits that continued experiencing pain despite being on the regular analgesic received a further dose of Butorphanol $0.5 \mathrm{mg} / \mathrm{kg}$ IM 12 hourly until they were pain free.

Animals that developed suture dehiscence or infection were isolated from the study animals and treated accordingly. Those with suture infection received topical antibiotic eye drops (gentamycin) for five days while those with suture dehiscence were examined for any eye infection and treated with topical antibiotics.

\subsection{Tissue harvesting}

Three control animals were sacrificed at the start of the study (14th postnatal day). This was on the same day the experimental animals had their eyelids sutured together. Thereafter nine rabbits, 3 controls and 6 experimental, were sacrificed each successive week, as shown in Table 1 below. Following weight determination, the rabbits were euthanized using intravenous Euthasol ${ }^{\circledR}$ (Sodium pentobarbital $390 \mathrm{mg} / \mathrm{ml}+$ sodium phenytoin $50 \mathrm{mg} / \mathrm{ml}$ ) at a dose of $1 \mathrm{~mL}$ per $4.5 \mathrm{Kg}$ body weight $(86.7 \mathrm{mg} / \mathrm{kg}$ pentobarbital and $11.1 \mathrm{mg} / \mathrm{kg}$ phenytoin). Once death was confirmed by loss of pupillary light reflex and corneal reflex, the thoracic cavity was opened then intra cardiac perfusion with normal saline commenced. Following perfusion, both eyes were enucleated then bisected along the vertical meridian. This was followed by removal of the vitreous humor from the eyecup so as to facilitate penetration of the fixing medium. The carcasses were incinerated after the tissues were harvested. 


\subsection{Tissue processing}

The retinae harvested were processed for light microscopic examination. Haematoxylin \& Eosin stain was used to demonstrate the different layers of the retina.

\subsection{Morphometric analysis}

Photomicrographs of the sections were taken using Canon ${ }^{\circledR}$ digital camera (12 megapixels). These photographs were transferred to a computer installed with ImageJ-Fiji software (SCHINDELIN, ARGANDA-CARRERAS, FRISE et al., 2012) for morphometric and stereological analysis. ImageJ is open source software developed by United States National Institute of Health for processing and analyzing images. It has inbuilt morphometric and stereological tools. The vertical thickness of each neural retinal layer were taken. So as to minimize intra-observer error, these measurements were taken from three different locations on the retina, and then averaged. Each measurement was expressed in micrometers.

\subsection{Statistical analysis}

Data collected were entered into the Statistical Package for Social Sciences software (Version 17.0, Chicago, Illinois) for coding, tabulation and statistical analysis. After confirming that the data was normally distributed using histograms and box plots, parametric tests were used to compare the means of the variables measured. Analysis of Variance (ANOVA) test was used to compare the means of each variable studied from baseline to the end of third week of study. The Student's t-test was used to compare the differences in means between the non-deprived and deprived eyes, non-deprived and control eyes, and deprived and control eyes. A $p$ value $<0.05$ was considered significant at $95 \%$ confidence interval.

\section{Results}

Of the thirty rabbits recruited into the study, one was excluded from the study as it developed suture dehiscence (dropout rate $3.3 \%$ ). Thus, fifty eight retina (from 29 rabbits) were studied. Retinae from all the study animals (experimental and control) had the classic layers of the neural retinae (Figure 1). The ganglion cell layer in all the retinae studied was one cell thick. All variables measured did not reveal any statistically significant differences between the right and left eyes.

\subsection{Deprived eyes}

The total thickness of the neural retina reduced with increasing duration of deprivation (Figure 2). The thickness of the neural retina at the start of the study, after week one, week two and week three of deprivation was $118.66 \pm 12.28 \mu \mathrm{m}$, $105.84 \pm 13.04 \mu \mathrm{m}, 94.37 \pm 25.06 \mu \mathrm{m}$, and $70.66 \pm 18.07 \mu \mathrm{m}$ respectively $(\mathrm{p}=0.001)$. There was generalized reduction in the thicknesses of all individual layers of the retina with increasing duration of deprivation (Table 2). The ANOVA test

Table 1. Study schedule.

\begin{tabular}{cccc}
\hline Study week & No. of control animals & \multicolumn{2}{c}{ No. of experimental animals } \\
\cline { 3 - 4 } & & Right eye sutured & Left eye sutured \\
\hline Week 0 (postnatal day 14) & 3 rabbits (baseline) & 3 & 3 \\
Week 1 (postnatal day 21) & 3 & 3 & 3 \\
Week 2 (postnatal day 28) & 3 & 3 & 3 \\
Week 3 (postnatal day 35) & 3 & & 3 \\
\hline
\end{tabular}
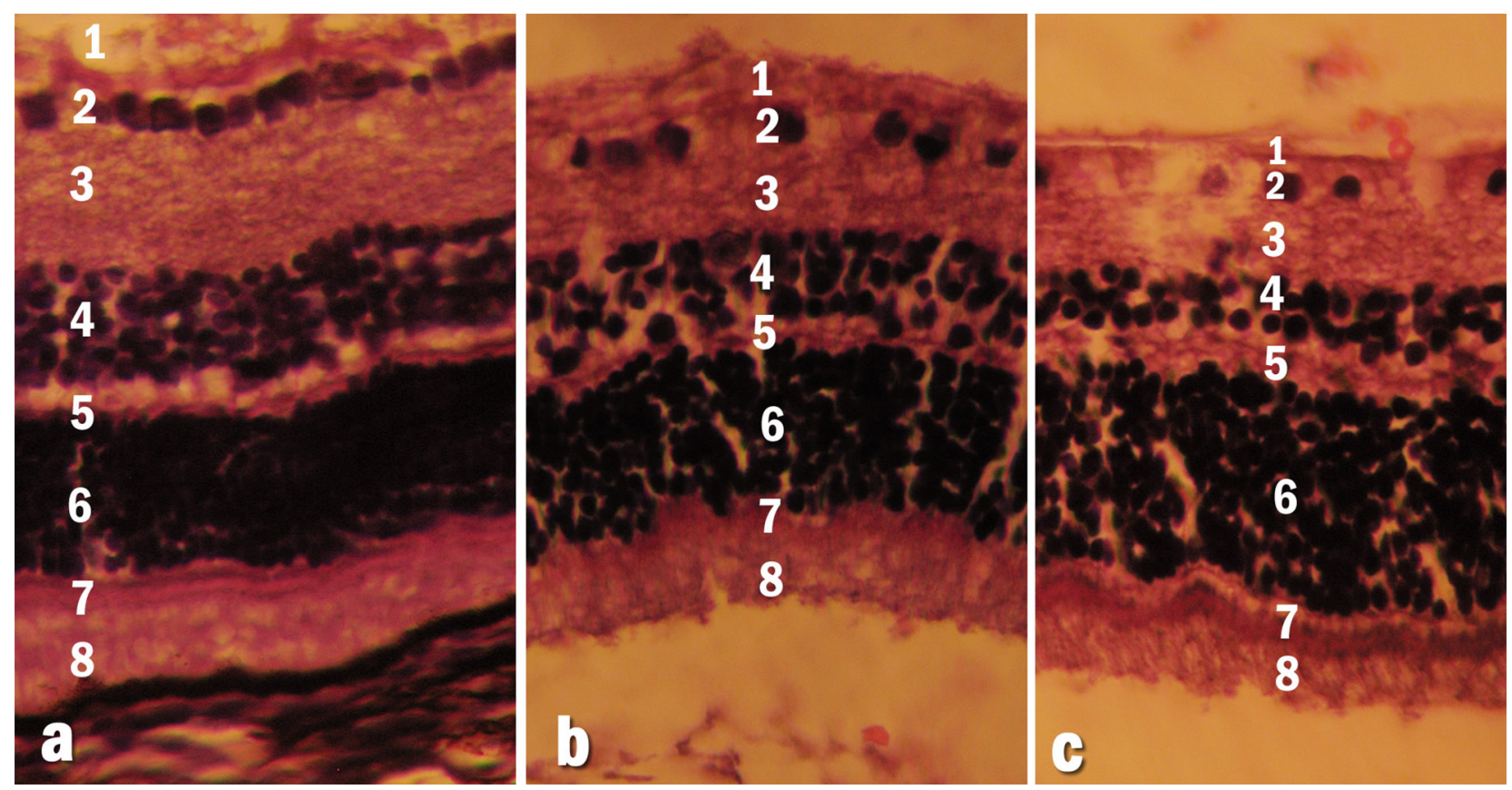

Figure 1. Photomicrograph displaying layers of neural retina in five week old rabbits. (a) Non deprived eye, (b) Control eye, (c) Deprived eye. Note the layers are numbered from the innermost to the outermost. 1- Nerve fiber layer, 2- ganglion cell layer, 3- inner plexiform layer, 4- inner nuclear layer, 5- outer plexiform layer, 6- outer nuclear layer, 7- outer limiting membrane, 8- rods and cones layer (Haematoxylin and Eosin stain, x92). 
revealed statistically significant reduction in the thickness of the inner plexiform $(58.4 \%, \mathrm{p}<0.001)$, inner nuclear $(50.3 \%$, $\mathrm{p}<0.001)$, rods and cones $(51.4 \%, \mathrm{p}=0.005)$ and ganglion cell $(39.7 \%, \mathrm{p}=0.008)$ layers only (Table 2$)$.

\subsection{Non-deprived eyes}

Figure 3 displays the retinae of non-sutured (non-deprived) eyes of the experimental rabbits after 1,2 , and 3 weeks of monocular deprivation. There was generalized increase in the thickness of the neural retina with increasing duration of deprivation but these changes were not statistically significant. The total neural retinal thickness in the non-deprived eye at the start of the study, after week one, week two and week three of deprivation was $119.36 \pm 12.75 \mu \mathrm{m}, 120.26 \pm 14.18 \mu \mathrm{m}$,
$125.96 \pm 13.38 \mu \mathrm{m}, 132.4 \pm 5.11 \mu \mathrm{m}$ respectively $(\mathrm{p}=0.075)$. Although the thickness of the layers of the retina in the non-deprived eyes increased with increasing period of monocular deprivation, ANOVA test revealed statistically significant differences in the inner plexiform and nerve fibre layers only (Table 2 ).

\subsection{Control eyes}

There were no marked changes in the thickness of the neural retina among the control eyes (Figure 4). The neural retina thickness at the start of the study, after week one, week two and week three of study were $119.36 \pm 12.75 \mu \mathrm{m}$, $114.85 \pm 15.82 \mu \mathrm{m}, 108.11 \pm 27.01 \mu \mathrm{m}, 109.10 \pm 9.48 \mu \mathrm{m}$ respectively $(\mathrm{p}=0.722)$. ANOVA test did not reveal any
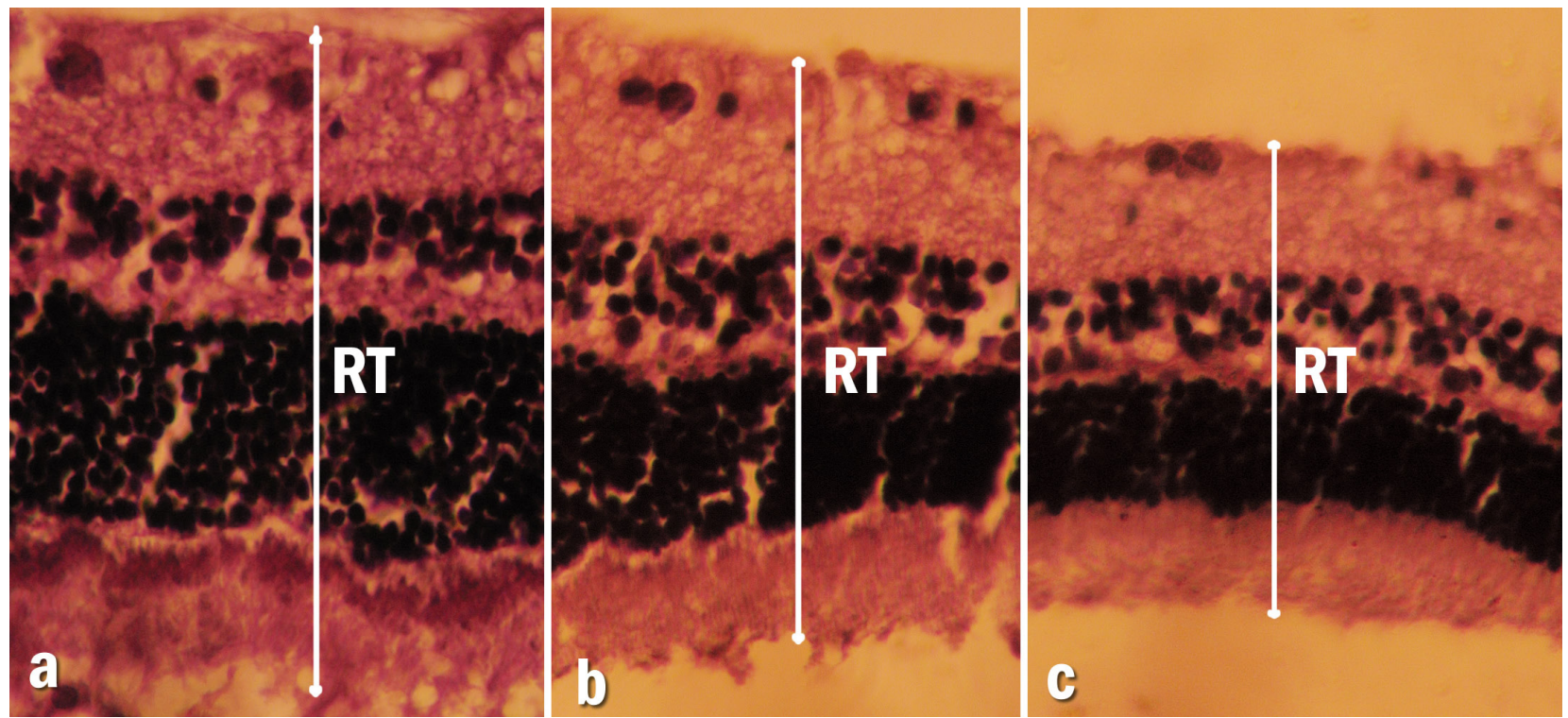

Figure 2. Photomicrograph of the neural retinal layer thickness in the deprived eyes. (a) After l week, (b) after 2 weeks, and (c) after 3 week of deprivation. Note that the neural retinal thickness (RT) decreases with increasing duration of deprivation (Haematoxylin and Eosin stain, x92).
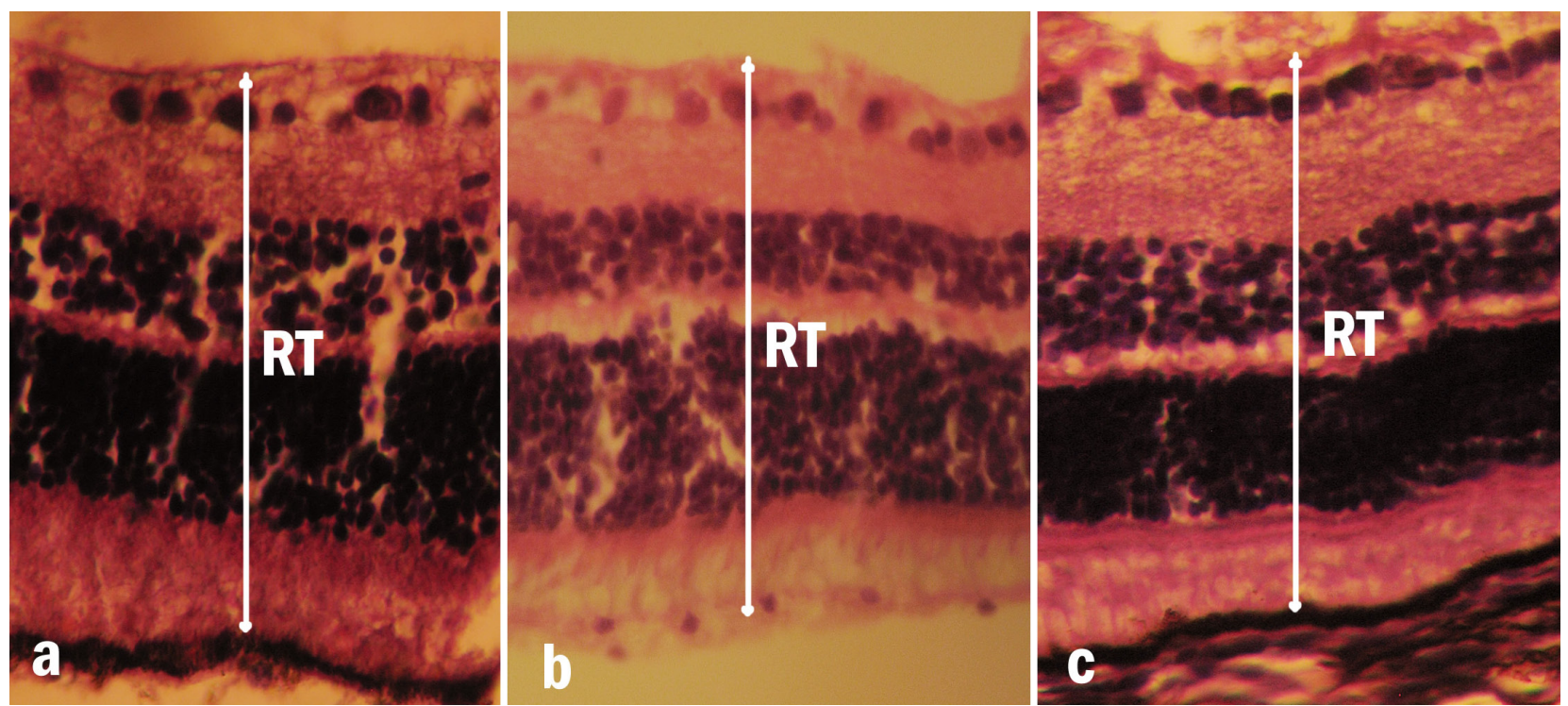

Figure 3. Photomicrograph of the neural retinal layer thickness in non-deprived eyes. (a) After 1 week of deprivation, (b) after 2 weeks of deprivation, (c) after 3 week of deprivation. Note that there is no marked difference in the neural retinal thickness (RT) with increasing duration of deprivation (Haematoxylin and Eosin stain, x92). 
Table 2. Changes in the retinal layer thicknesses in the deprived, non-deprived, and control eyes.

\begin{tabular}{|c|c|c|c|c|c|c|c|c|c|c|}
\hline \multirow{2}{*}{$\begin{array}{c}\text { Retinal } \\
\text { layer }\end{array}$} & \multirow{2}{*}{$\begin{array}{c}\text { Deprivation } \\
\text { time (weeks) }\end{array}$} & \multicolumn{3}{|c|}{ Deprived eyes } & \multicolumn{3}{|c|}{ Non deprived eyes } & \multicolumn{3}{|c|}{ Controls } \\
\hline & & $\begin{array}{l}\text { Mean } \\
(\mu \mathrm{m})\end{array}$ & $\begin{array}{c}\text { Standard } \\
\text { Deviation }\end{array}$ & p-value & $\begin{array}{l}\text { Mean } \\
(\mu \mathrm{m})\end{array}$ & $\begin{array}{c}\text { Standard } \\
\text { Deviation }\end{array}$ & p-value & $\begin{array}{l}\text { Mean } \\
(\mu \mathrm{m})\end{array}$ & $\begin{array}{c}\text { Standard } \\
\text { Deviation }\end{array}$ & p-value \\
\hline \multirow{4}{*}{$\begin{array}{l}\text { Rod and } \\
\text { cones layer }\end{array}$} & 0 & 23.53 & 7.66 & \multirow{4}{*}{$0.005^{*}$} & 23.53 & 7.66 & \multirow{4}{*}{0.977} & 23.53 & 7.66 & \multirow{4}{*}{0.162} \\
\hline & 1 & 18.99 & 4.35 & & 23.81 & 2.12 & & 20.57 & 3.39 & \\
\hline & 2 & 16.30 & 5.99 & & 24.10 & 3.00 & & 18.41 & 4.28 & \\
\hline & 3 & 11.44 & 3.69 & & 24.45 & 5.47 & & 17.83 & 1.41 & \\
\hline \multirow{4}{*}{$\begin{array}{c}\text { Outer } \\
\text { limiting } \\
\text { Membrane }\end{array}$} & 0 & 4.51 & 0.52 & \multirow{4}{*}{0.941} & 4.51 & 0.52 & \multirow{4}{*}{0.676} & 4.51 & 0.52 & \multirow{4}{*}{0.952} \\
\hline & 1 & 4.51 & 0.97 & & 4.83 & 1.86 & & 4.66 & 0.95 & \\
\hline & 2 & 4.49 & 1.66 & & 5.07 & 1.28 & & 4.73 & 1.21 & \\
\hline & 3 & 4.37 & 1.95 & & 5.37 & 1.24 & & 4.81 & 0.59 & \\
\hline \multirow{4}{*}{$\begin{array}{c}\text { Outer } \\
\text { nuclear layer }\end{array}$} & 0 & 36.43 & 5.26 & \multirow{4}{*}{0.460} & 36.43 & 5.26 & \multirow{4}{*}{0.938} & 36.43 & 5.26 & \multirow{4}{*}{0.978} \\
\hline & 1 & 33.06 & 9.07 & & 35.15 & 6.56 & & 36.45 & 5.77 & \\
\hline & 2 & 31.53 & 11.12 & & 34.99 & 9.18 & & 36.51 & 13.34 & \\
\hline & 3 & 26.58 & 14.62 & & 34.16 & 3.71 & & 36.60 & 7.86 & \\
\hline \multirow{4}{*}{$\begin{array}{l}\text { Outer } \\
\text { plexiform } \\
\text { layer }\end{array}$} & 0 & 7.07 & 2.03 & \multirow{4}{*}{0.245} & 7.07 & 1.58 & \multirow{4}{*}{0.828} & 7.07 & 1.58 & \multirow{4}{*}{0.997} \\
\hline & 1 & 7.05 & 3.70 & & 7.18 & 3.12 & & 7.07 & 0.09 & \\
\hline & 2 & 5.73 & 2.38 & & 7.29 & 0.69 & & 7.30 & 3.89 & \\
\hline & 3 & 4.41 & 1.70 & & 7.90 & 1.83 & & 7.34 & 1.07 & \\
\hline \multirow{4}{*}{$\begin{array}{c}\text { Inner } \\
\text { nuclear layer }\end{array}$} & 0 & 16.49 & 3.16 & \multirow{4}{*}{$<0.001$ * } & 16.49 & 3.16 & \multirow{4}{*}{0.109} & 16.49 & 3.16 & \multirow{4}{*}{0.413} \\
\hline & 1 & 15.09 & 3.24 & & 16.95 & 2.61 & & 17.39 & 3.20 & \\
\hline & 2 & 12.66 & 1.95 & & 18.12 & 2.19 & & 16.07 & 4.87 & \\
\hline & 3 & 8.29 & 2.07 & & 19.81 & 4.15 & & 13.89 & 1.32 & \\
\hline \multirow{4}{*}{$\begin{array}{c}\text { Inner } \\
\text { plexiform } \\
\text { layer }\end{array}$} & 0 & 20.51 & 5.24 & \multirow{4}{*}{$<0.001 *$} & 20.51 & 5.24 & & 20.51 & 5.24 & \\
\hline & 1 & 17.67 & 5.39 & & 20.41 & 4.35 & & 20.18 & 3.86 & \\
\hline & 2 & 14.20 & 3.82 & & 22.73 & 4.38 & $0.012^{*}$ & 14.79 & 7.86 & 0.195 \\
\hline & 3 & 8.53 & 2.45 & & 26.53 & 4.41 & & 14.17 & 5.21 & \\
\hline & 0 & 5.84 & 0.83 & & 5.84 & 0.83 & & 5.84 & 0.83 & \\
\hline Ganglion & 1 & 5.88 & 1.18 & & 6.93 & 1.80 & & 7.06 & 0.88 & \\
\hline cell layer & 2 & 5.49 & 1.80 & $0.008^{*}$ & 7.13 & 1.29 & 0.285 & 7.44 & 2.46 & 0.425 \\
\hline & 3 & 3.59 & 0.65 & & 7.19 & 0.84 & & 7.50 & 1.81 & \\
\hline & 0 & 4.98 & 2.17 & & 4.98 & 2.17 & & 4.98 & 2.17 & \\
\hline Nerve fibre & 1 & 4.46 & 1.21 & 0 & 4.99 & 1.39 & & 4.72 & 2.23 & \\
\hline layer & 2 & 3.97 & 1.69 & 0.200 & 6.55 & 2.21 & $0.033^{*}$ & 4.97 & 0.73 & 0.214 \\
\hline & 3 & 3.46 & 0.59 & & 6.99 & 1.69 & & 6.96 & 2.97 & \\
\hline
\end{tabular}

* p-value $<0.05$

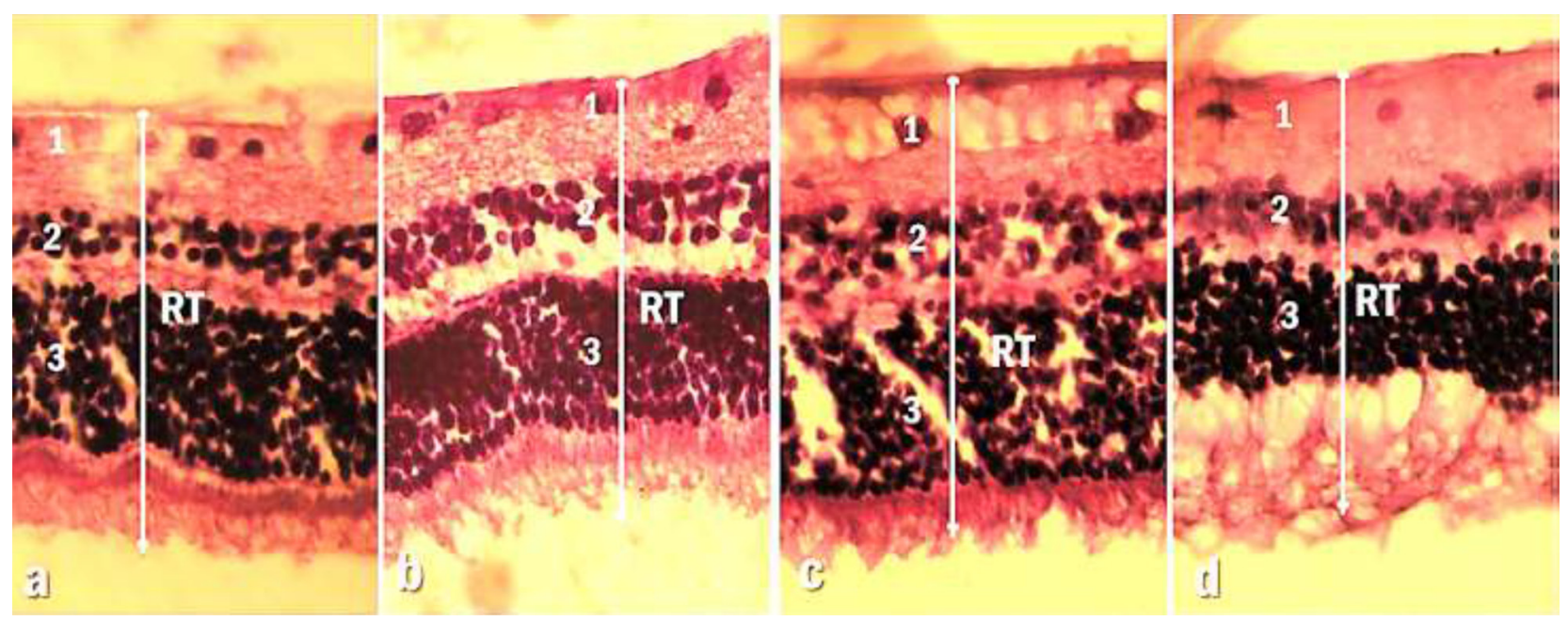

Figure 4. Photomicrograph of the neural retinal layer thickness among control eyes. (a) at the start of study (week 0), (b) at the end of first week of study, (c) at the end of second week of study, (d) at the end of third week of study. For orientation, the cell body layers are marked 1-3. 1-Ganglion cell layer, 2-Inner nuclear layer, 3- outer nuclear layer. Note that there is no marked difference in the overall neural retinal thickness (RT) with increasing age (Haematoxylin and Eosin stain, x92). 
statistically significant differences in the thickness of the individual layers of the retina among the control eyes (Table 2).

\subsection{Comparison between deprived and non-deprived eyes}

The deprived eyes retinal layers were thinner than the non-deprived counterparts, with the differences in thickness being marked with increasing duration of deprivation. Comparison of the differences in means in the retinal layer measurements between the non-deprived and deprived eyes, using Student's $t$-test, revealed statistically significant differences in all layers of the retina apart from the outer nuclear layer and outer limiting membrane (Table 3).

\subsection{Comparison between deprived and control eyes}

The deprived eyes retinae had thinner retinae compared to the control eyes, with the differences being more marked with increasing duration of deprivation. Comparison of the differences in means in the retinal layer measurements after three weeks of deprivation, using Student's $t$-test, revealed statistically significant differences in all layers apart from the outer limiting membrane and outer nuclear layer (Table 4).

\subsection{Comparison between non-deprived and control eyes}

The non-deprived eyes had thicker retina compared to the controls. Comparison of the means between the non-deprived and control eyes using Student's $t$-test revealed statistically significant differences in the rod and cones, inner nuclear, and inner plexiform layers at the end of the third week of deprivation (Table 5).

\section{Discussion}

The present study has revealed that monocular deprivation leads to significant reduction in the neural retinal thickness of the deprived eyes compared to controls and non-deprived eyes.
This is in agreement with previous studies on monocularly deprived mice (ZHOU, AN, WU et al., 2010) and tree shrews (ABBOTT, GRÜNERT, PIANTA et al., 2011). Similar findings have been reported in other stimulus deprived receptor organs such as the olfactory mucosa after unilateral naris occlusion (COPPOLA, 2012; HUART, ROMBAUX and HUMMEL, 2013), and the organ of Corti after unilateral hearing loss (TERAYAMA, KANEKO, KAWAMOTO et al., 1977; SYKA, 2002). For instance, in the olfactory mucosa, the occluded side becomes significantly thinner compared to the open side (COPPOLA, 2012; HUART, ROMBAUX and HUMMEL, 2013). These findings have been attributed to under-expression of pro-mitotic genes and increased expression of apoptotic genes in the deprived side leading to reduced cellular proliferation (FIRSZT, REEDER, HOLDEN et al., 2013; ZHAO, TIAN, MA et al., 2013). In the retina, growth factors such as Brain Derived Neurotrophic Factor (BDNF) have been shown to influence its cellular proliferation (SEKI, NAWA, FUKUCHI et al., 2003; MANDOLESI, MENNA, HARAUZOV et al., 2005). In monocularly deprived eyes, BDNF expression is reduced in the deprived eyes and increased in the non-deprived eyes (SEKI, NAWA, FUKUCHI et al., 2003). Consequently, the reduction in the retinal thickness in the deprived eyes in the current study could be as a result of reduced proliferation of the retinal cells due to reduced expression of promitotic factors such as BDNF or increased expression of apoptotic factors.

The deprived eyes in the present study had statistically significant thinner rods and cones layer compared to controls. The non-deprived eyes on the other hand had thicker rods and cones layer compared to controls. These findings are hitherto undescribed. The rods and cones layer is made up of the outer segments of the photoreceptors which contain visual pigments such as rhodopsin (MESCHER, 2005). Biosynthesis of visual pigments especially rhodopsin is a light dependent process (SCHWEMER, 1984). It is therefore plausible that lack of

Table 3. Comparison of retinal layer thicknesses between deprived and non-deprived eyes.

\begin{tabular}{|c|c|c|c|c|c|c|c|}
\hline \multirow[b]{2}{*}{ Retinal layer } & \multirow[b]{2}{*}{ Eye } & \multicolumn{2}{|c|}{ Week 1} & \multicolumn{2}{|c|}{ Week 2} & \multicolumn{2}{|c|}{ Week 3} \\
\hline & & $\begin{array}{l}\text { Mean } \\
(\mu m)\end{array}$ & $p$ value & $\begin{array}{l}\text { Mean } \\
(\mu m)\end{array}$ & $p$ value & $\begin{array}{r}\text { Mean } \\
(\mu m)\end{array}$ & $\mathrm{p}$ value \\
\hline \multirow{2}{*}{ Retinal thickness } & Deprived & 106.71 & \multirow{2}{*}{$0.034^{*}$} & 95.32 & \multirow{2}{*}{$0.002^{*}$} & 70.95 & \multirow{2}{*}{$<0.001^{*}$} \\
\hline & Non deprived & 120.26 & & 125.96 & & 132.40 & \\
\hline \multirow{2}{*}{ Rod and cones layer } & Deprived & 18.99 & \multirow{2}{*}{$0.002^{*}$} & 16.30 & \multirow{2}{*}{$0.001^{*}$} & 11.44 & \multirow{2}{*}{$<0.001^{*}$} \\
\hline & Non deprived & 23.81 & & 24.10 & & 24.45 & \\
\hline \multirow{2}{*}{$\begin{array}{l}\text { Outer limiting } \\
\text { Membrane }\end{array}$} & Deprived & 4.51 & \multirow{2}{*}{0.651} & 4.49 & \multirow{2}{*}{0.368} & 4.37 & \multirow{2}{*}{0.197} \\
\hline & Non deprived & 4.83 & & 5.07 & & 5.37 & \\
\hline \multirow{2}{*}{ Outer nuclear layer } & Deprived & 33.06 & \multirow{2}{*}{0.536} & 31.53 & \multirow{2}{*}{0.436} & 26.58 & \multirow{2}{*}{0.116} \\
\hline & Non deprived & 35.15 & & 34.99 & & 34.16 & \\
\hline \multirow{2}{*}{ Outer plexiform layer } & Deprived & 7.05 & \multirow{2}{*}{0.930} & 5.78 & \multirow{2}{*}{0.058} & 4.69 & \multirow{2}{*}{$0.003^{*}$} \\
\hline & Non deprived & 7.18 & & 7.29 & & 7.90 & \\
\hline \multirow{2}{*}{ Inner nuclear layer } & Deprived & 15.09 & \multirow{2}{*}{0.151} & 13.57 & \multirow{2}{*}{$0.003^{*}$} & 8.29 & \multirow{2}{*}{$<0.001^{*}$} \\
\hline & Non deprived & 16.95 & & 18.12 & & 19.81 & \\
\hline \multirow{2}{*}{ Inner plexiform layer } & Deprived & 17.67 & \multirow{2}{*}{0.203} & 14.20 & \multirow{2}{*}{$<0.001^{*}$} & 8.53 & \multirow{2}{*}{$<0.001$ * } \\
\hline & Non deprived & 20.41 & & 22.73 & & 26.53 & \\
\hline \multirow{2}{*}{ Ganglion cell layer } & Deprived & 5.88 & \multirow{2}{*}{0.139} & 5.49 & & 3.59 & \\
\hline & Non deprived & 6.93 & & 7.13 & $0.023^{*}$ & 7.19 & $<0.001^{*}$ \\
\hline & Deprived & 4.46 & & 3.97 & & 3.46 & \\
\hline Nerve fibre layer & Non deprived & 4.99 & 0.360 & 6.55 & $0.006^{*}$ & 6.99 & $<0.001^{*}$ \\
\hline
\end{tabular}


Table 4. Comparison of retinal layer thicknesses between deprived and control eyes.

\begin{tabular}{|c|c|c|c|c|c|c|c|}
\hline \multirow[b]{2}{*}{ Retinal layer } & \multirow[b]{2}{*}{ Eye } & \multicolumn{2}{|c|}{ Week 1} & \multicolumn{2}{|c|}{ Week 2} & \multicolumn{2}{|c|}{ Week 3} \\
\hline & & $\begin{array}{l}\text { Mean } \\
(\mu m)\end{array}$ & $p$ value & $\begin{array}{l}\text { Mean } \\
(\mu m)\end{array}$ & $p$ value & $\begin{array}{r}\text { Mean } \\
(\mu m)\end{array}$ & $p$ value \\
\hline \multirow{2}{*}{ Total Retinal thickness } & Deprived & 106.71 & \multirow{2}{*}{0.348} & 95.32 & \multirow{2}{*}{0.279} & 70.95 & \multirow{2}{*}{$<0.001^{*}$} \\
\hline & Control & 114.85 & & 108.11 & & 109.10 & \\
\hline \multirow{2}{*}{ Rod and cones layer } & Deprived & 18.99 & \multirow{2}{*}{0.537} & 16.30 & \multirow{2}{*}{0.387} & 11.44 & \multirow{2}{*}{$0.001^{*}$} \\
\hline & Control & 20.57 & & 18.41 & & 17.83 & \\
\hline \multirow{2}{*}{$\begin{array}{c}\text { Outer limiting } \\
\text { Membrane }\end{array}$} & Deprived & 4.51 & \multirow{2}{*}{0.809} & 4.49 & \multirow{2}{*}{0.716} & 4.37 & \multirow{2}{*}{0.575} \\
\hline & Control & 4.66 & & 4.73 & & 4.81 & \\
\hline \multirow{2}{*}{ Outer nuclear layer } & Deprived & 33.06 & \multirow{2}{*}{0.510} & 31.53 & \multirow{2}{*}{0.373} & 26.58 & \multirow{2}{*}{0.136} \\
\hline & Control & 36.45 & & 36.51 & & 36.60 & \\
\hline \multirow{2}{*}{ Outer plexiform layer } & Deprived & 7.05 & \multirow{2}{*}{0.992} & 5.78 & \multirow{2}{*}{0.296} & 4.69 & \multirow{2}{*}{$0.008^{*}$} \\
\hline & Control & 7.07 & & 7.30 & & 7.34 & \\
\hline \multirow{2}{*}{ Inner nuclear layer } & Deprived & 15.09 & \multirow{2}{*}{0.260} & 13.57 & \multirow{2}{*}{0.213} & 8.29 & \multirow{2}{*}{$<0.001^{*}$} \\
\hline & Control & 17.39 & & 16.07 & & 13.89 & \\
\hline \multirow{2}{*}{ Inner plexiform layer } & Deprived & 17.67 & \multirow{2}{*}{0.423} & 14.20 & \multirow{2}{*}{0.830} & 8.53 & \multirow{2}{*}{$0.024^{*}$} \\
\hline & Control & 20.18 & & 14.79 & & 14.17 & \\
\hline \multirow{2}{*}{ Ganglion cell layer } & Deprived & 5.88 & \multirow{2}{*}{0.103} & 5.49 & 0.055 & 3.59 & 1 * \\
\hline & Control & 7.06 & & 7.44 & 0.055 & 7.50 & $<0.001 n$ \\
\hline Nerpe fiher laver & Deprived & 4.46 & & 3.97 & & 3.46 & 0 \\
\hline Nerve floer layer & Control & 4.72 & 0.781 & 4.97 & 0.110 & 6.96 & 0.010 \\
\hline
\end{tabular}

Table 5. Comparison of retinal layer thicknesses between non-deprived and control eyes.

\begin{tabular}{|c|c|c|c|c|c|c|c|}
\hline \multirow[b]{2}{*}{ Retinal layer } & \multirow[b]{2}{*}{ Eye } & \multicolumn{2}{|c|}{ Week 1} & \multicolumn{2}{|c|}{ Week 2} & \multicolumn{2}{|c|}{ Week 3} \\
\hline & & $\begin{array}{c}\text { Mean } \\
(\mu m)\end{array}$ & $\mathrm{p}$ value & $\begin{array}{c}\text { Mean } \\
(\mu m)\end{array}$ & p value & $\begin{array}{r}\text { Mean } \\
(\mu m)\end{array}$ & $p$ value \\
\hline \multirow{2}{*}{$\begin{array}{l}\text { Total Retinal } \\
\text { thickness }\end{array}$} & Non deprived & 120.26 & \multirow[t]{2}{*}{0.525} & 125.96 & \multirow{2}{*}{0.070} & 132.40 & \multirow{2}{*}{$<0.001$ * } \\
\hline & Control & 114.85 & & 108.11 & & 109.10 & \\
\hline \multirow{2}{*}{ Rod and cones layer } & Non deprived & 23.81 & \multirow[t]{2}{*}{$0.033^{*}$} & 24.10 & \multirow{2}{*}{$0.003^{*}$} & 24.45 & \multirow{2}{*}{$0.007^{*}$} \\
\hline & Control & 20.57 & & 18.41 & & 17.83 & \\
\hline \multirow{2}{*}{$\begin{array}{c}\text { Outer limiting } \\
\text { Membrane }\end{array}$} & Non deprived & 4.83 & \multirow[t]{2}{*}{0.867} & 5.07 & \multirow{2}{*}{0.556} & 5.37 & \multirow{2}{*}{0.282} \\
\hline & Control & 4.66 & & 4.73 & & 4.81 & \\
\hline \multirow{2}{*}{ Outer nuclear layer } & Non deprived & 35.15 & \multirow[t]{2}{*}{0.727} & 34.99 & \multirow{2}{*}{0.765} & 34.16 & \multirow{2}{*}{0.384} \\
\hline & Control & 36.45 & & 36.51 & & 36.60 & \\
\hline \multirow{2}{*}{$\begin{array}{c}\text { Outer plexiform } \\
\text { layer }\end{array}$} & Non deprived & 7.18 & \multirow[t]{2}{*}{0.946} & 7.29 & \multirow{2}{*}{0.993} & 7.90 & \multirow{2}{*}{0.477} \\
\hline & Control & 7.07 & & 7.30 & & 7.34 & \\
\hline \multirow{2}{*}{ Inner nuclear layer } & Non deprived & 16.95 & \multirow[t]{2}{*}{0.781} & 18.12 & \multirow{2}{*}{0.225} & 19.81 & \multirow{2}{*}{$0.002^{*}$} \\
\hline & Control & 17.39 & & 16.07 & & 13.89 & \\
\hline \multirow{2}{*}{$\begin{array}{c}\text { Inner plexiform } \\
\text { layer }\end{array}$} & Non deprived & 20.41 & \multirow[t]{2}{*}{0.926} & 22.73 & \multirow{2}{*}{$0.010^{*}$} & 26.53 & \multirow{2}{*}{$<0.001 *$} \\
\hline & Control & 20.18 & & 14.79 & & 14.17 & \\
\hline \multirow{2}{*}{ Ganglion cell layer } & Non deprived & 6.93 & \multirow[t]{2}{*}{0.895} & 7.13 & 0718 & 7.19 & 0623 \\
\hline & Control & 7.06 & & 7.44 & 0.718 & 7.50 & 0.623 \\
\hline Nerne fher lawer & Non deprived & 4.99 & 0.771 & 6.55 & & 6.99 & \\
\hline Nerve fiber layer & Control & 4.72 & & 4.97 & 0.056 & 6.96 & 0.977 \\
\hline
\end{tabular}

${ }^{*} \mathrm{p}<0.05$.

light as in the case with the deprived eyes in the current study may have resulted into reduced synthesis of the visual pigments leading to reduction in the thickness of the rods and cones layer. On the other hand, presence of light may have caused increased synthesis of the photo pigments leading to increase in the thickness of this layer among the non-deprived eyes.

The outer nuclear layer contains the cell bodies of photoreceptors (MASLAND, 2012). In the present study, this layer was relatively not affected by visual deprivation. There were no statistically significant differences in the thickness of this layer between the deprived and control eyes. ABBOTT et al. 2011, who studied three tree shrews that had been monocularly deprived of light for 19 months, reported that the deprived eyes had significantly thinner outer nuclear layer compared to the non-deprived eye. The differences noted between our study and this previous study could be due to the differences in duration of deprivation, species of animal, or the sample size used. In the same study however the authors noted that the outer nuclear layer contributed least in the total thinning of the retina among the deprived eyes (ABBOTT, GRÜNERT, 
PIANTA et al., 2011). Thus, visual deprivation has little effect on the thickness of the outer nuclear layer.

In the present study, the non-deprived eyes had thinner outer nuclear layer compared to controls, with the differences being more marked with increasing period of deprivation. This concurs with the findings by FIFKOVA, 1972, who reported that increasing duration of deprivation resulted to greater decrease in the thickness of outer nuclear layer of non-deprived eyes compared to the controls. This author postulated that the animal with one eye keeps it more open compared to the one with both eyes open, leading to damage to the photoreceptors as a result of over stimulation (FIFKOVÁ, 1972). Subsequent studies have demonstrated that prolonged exposure to light leads to damage to the photoreceptors (ORGANISCIAK and VAUGHAN, 2010; MARCHIAFAVA, 2012; OKANO, MAEDA, CHEN et al., 2012). It is therefore plausible that the experimental animals kept open their non-deprived eyes for a longer duration leading to damage to the photoreceptors which in turn lead reduction in the thickness of the outer nuclear layer compared to the controls.

Compared to controls, the deprived eyes had statistically significant reduction in the thickness of the inner nuclear layer with increasing duration of deprivation. On the other hand, the non-deprived eyes had generally thicker inner nuclear layer compared with the controls. Our findings are in accord with those of a study by Abbott, Grünert, Pianta et al. (2011), who demonstrated that monocular deprivation resulted into statistically significant thinning of the inner nuclear layer in the deprived eyes compared to non-deprived eyes. The inner nuclear layer contains the somata of the bipolar, amacrine and horizontal cells (KOLB, FERNANDEZ, NELSON, 1995; MASLAND, 2012). Proliferation of these cells is dependent on the interplay between extrinsic factors such as presence of light stimulus, and intrinsic factors such as growth factors (TROPEPE, COLES, CHIASSON et al., 2000; FISCHER, DIERKS and REH, 2002; LI, PERISSI, LIU et al., 2002). For instance, Brain-Derived Neurotrophic Factor (BDNF) which is a nerve growth factor, has been localized in the inner nuclear cells (PEREZ and CAMINOS, 1995; VECINO, CAMINOS, UGARTE et al., 1998), and has been shown to influence retinal cell proliferation. Monocular deprivation has been shown to result in reduced expression of BDNF in deprived eyes compared to the non-deprived counterparts (SEKI, NAWA, FUKUCHI et al., 2003). Consequently, absence of light stimulus could have caused reduced expression of BDNF in the deprived eyes leading to reduced cellular proliferation and subsequent thinning of the inner nuclear layer.

The ganglion cell layer contains the cell bodies of the ganglion neurons while the nerve fibre layer contains the axons of these neurons (MASLAND, 2012). In the current study, the ganglion cell and nerve fibre layers in the deprived eyes were significantly thinner compared the controls and the non-deprived eyes. Thinning of the ganglion cell as well as the nerve fibre layers resulting from deprivation has been reported in previous studies (ABBOTT, GRÜNERT, PIANTA et al., 2011; SZUMIŃSKI and BAKUNOWICZ-ŁAZARCZYK, 2012; ZHAO and JIANG, 2013). Proliferation of the ganglion cells has also been shown to be influenced by growth factors such as retinal BDNF (SEKI, NAWA, FUKUCHI et al., 2003; MANDOLESI, MENNA, HARAUZOV et al., 2005). BDNF has also been localized in the retinal ganglion cells (PEREZ and CAMINOS, 1995; VECINO, CAMINOS, UGARTE et al.,
1998), and monocular deprivation has been shown to result in reduced expression of BDNF in deprived eyes compared to the non-deprived counterparts (SEKI, NAWA, FUKUCHI et al., 2003). Thus, the reduction in the thickness of the ganglion cell and nerve fibre layers seen in the deprived eyes could have resulted from reduced proliferation of the ganglion cells as a result of reduced expression of growth factors such as BDNF as a result of light deprivation.

In the present study, the thickness of the inner plexiform layer among the deprived eyes significantly reduced with increasing time of deprivation. Abbott, Grünert, Pianta (2011), also reported that the inner plexiform layer of monocularly deprived eyes of tree shrews was significantly thinner compared to control eyes. The inner plexiform layer contains synapses between the bipolar and ganglion cells, as well as between the amacrine and ganglion cells (KOLB, FERNANDEZ, NELSON, 1995; MASLAND, 2012). Synaptic plasticity involves strengthening or weakening of synapses over time in response to increase or decrease in the synaptic activity (ANTONINI, FAGIOLINI and STRYKER, 1999; TRACHTENBERG and STRYKER, 2001; HO, LEE and MARTIN, 2011). Monocular deprivation has been shown to lead to shrinkage of the primary visual cortex and the lateral geniculate nucleus of the deprived eye as a result of reduction in the synaptic activity in these areas (DAW, 2006; HOFER, MRSIC-FLOGEL, BONHOEFFER et al., 2006; HAYANO and YAMAMOTO, 2008; LINDEN, HEYNEN, HASLINGER et al., 2009). Consequently, the reduction in the thickness of the inner plexiform layer observed among deprived eyes could be as a result of reduced synaptic activity in this layer due to visual deprivation.

\section{Conclusion}

The present study has demonstrated that monocular deprivation results in activity-dependent changes in the neural retina. These changes include retinal atrophy, reduction in all cell densities and reduction in the dendrites of ganglion neurons in the deprived eyes. On the other hand, the non-deprived eyes experience compensatory increase in neural retinal thickness, cell densities and the dendrites of the ganglion cells. In both the deprived and non-deprived eyes, most changes were seen in the layers associated with the neurons namely, nerve fibre layer, ganglion cell layer, inner plexiform, and inner nuclear layer. These changes in the retina may contribute to the changes seen in the visual cortex in monocularly deprived animals. Thus, pre-retinal causes of blindness such as cataracts affects the retina in a similar way as the visual cortex. However, there is need for further studies to determine whether these changes in the retina are reversible, and if they are, then the maximum period of deprivation beyond which these changes cannot occur should be ascertained. This would inform eye specialists on the timing of the corrective surgery for pre-retinal causes of blindness such as cataracts.

\section{References}

ABBOTT, CJ., GRÜNERT, U., PIANTA, MJ. and MCBRIEN, NA. Retinal thinning in tree shrews with induced high myopia: Optical coherence tomography and histological assessment. Vision Research, 2011, vol. 51, n. 3, p. 376-385. http://dx.doi.org/10.1016/j. visres.2010.12.005. PMid:21156186. 
AMTHOR, FR., TAKAHASHI, ES. and OYSTER, CW. Morphologies of rabbit retinal ganglion cells with complex receptive fields. The Journal of Comparative Neurology, 1989, vol. 280, n. 1, p. 97-121. http:// dx.doi.org/10.1002/cne.902800108. PMid:2918098.

ANTONINI, A., FAGIOLINI, M. and STRYKER, MP. Anatomical correlates of functional plasticity in mouse visual cortex. The Journal of Neuroscience, 1999, vol. 19, n. 11, p. 4388-4406. PMid:10341241.

BARO, JA., LEHMKUHLE, S. and KRATZ, KE. Electroretinograms and visual evoked potentials in long-term monocularly deprived cats. Investigative Ophthalmology \& Visual Science, 1990, vol. 31, n. 7, p. 1405-1409. PMid:2365572.

COPPOLA, DM. Studies of Olfactory system neural plasticity: the contribution of the unilateral naris occlusion technique. Neural Plasticity, 2012, vol. 2012, p. 1-14. http://dx.doi.org/10.1155/2012/351752. PMid:22690343.

DAW, N. Mechanisms of plasticity in the visual cortex. In DAW, N. Visual development. New York: Springer, 2006. p. 207-233.

DEWS, PB. and WIESEL, TN. Consequences of monocular deprivation on visual behaviour in kittens. The Journal of Physiology, 1970, vol. 206, n. 2, p. 437-455. http://dx.doi.org/10.1113/jphysiol.1970. sp009023. PMid:5498494.

ELLEMBERG, D., LEWIS, TL., MAURER, D. and BRENT, HP. Influence of monocular deprivation during infancy on the later development of spatial and temporal vision. Vision Research, 2000, vol. 40, n. 23, p. 3283-3295. http://dx.doi.org/10.1016/S00426989(00)00165-6. PMid:11008144.

FIFKOVÁ, E. Effect of light and visual deprivation on the retina. Experimental Neurology, 1972, vol. 35, n. 3, p. 450-457. http:// dx.doi.org/10.1016/0014-4886(72)90115-X. PMid:5035154.

FIRSZT, JB., REEDER, RM., HOLDEN, TA., BURTON, H. and CHOLE, RA. Changes in auditory perceptions and cortex resulting from hearing recovery after extended congenital unilateral hearing loss. Frontiers in Systems Neuroscience, 2013, vol. 7, p. 108. http:// dx.doi.org/10.3389/fnsys.2013.00108. PMid:24379761.

FISCHER, AJ., DIERKS, BD. and REH, TA. Exogenous growth factors induce the production of ganglion cells at the retinal margin. Development, 2002, vol. 129, n. 9, p. 2283-2291. PMid:11959835.

HAYANO, Y. and YAMAMOTO, N. Activity-dependent thalamocortical axon branching. The Neuroscientist, 2008, vol. 14, n. 4, p. 359-368. http://dx.doi.org/10.1177/1073858408317272. PMid:18660463.

HO, VM., LEE, J-A. and MARTIN, KC. The cell biology of synaptic plasticity. Science, 2011, vol. 334, n. 6056, p. 623-628. http://dx.doi. org/10.1126/science.1209236. PMid:22053042.

HOFER, SB., MRSIC-FLOGEL, TD., BONHOEFFER, T. and HÜBENER, M. Prior experience enhances plasticity in adult visual cortex. Nature Neuroscience, 2006, vol. 9, n. 1, p. 127-132. http:// dx.doi.org/10.1038/nnl610. PMid:16327785.

HUART, C., ROMBAUX, P. and HUMMEL, T. Plasticity of the human olfactory system: the olfactory bulb. Molecules (Basel, Switzerland), 2013, vol. 18, n. 9, p. 11586-11600. http://dx.doi.org/10.3390/ molecules180911586. PMid:24048289.

KOLB, HH., FERNANDEZ, EE. and NELSON, RR., (Eds.). Webvision: the organization of the retina and visual system. Salt Lake City: University of Utah Health Sciences Center, 1995.

LEHMANN, K. and LÖWEL, S. Age-dependent ocular dominance plasticity in adult mice. PLoS One, 2008, vol. 3, n. 9, p. e3120. http:// dx.doi.org/10.1371/journal.pone.0003120. PMid:18769674.

LEWIS, T. and MAURER, D. Multiple sensitive periods in human visual development: evidence from visually deprived children. Developmental Psychobiology, 2005, vol. 46, n. 3, p. 163-183. http:// dx.doi.org/10.1002/dev.20055. PMid:15772974.
LI, X., PERISSI, V., LIU, F., ROSE, DW. and ROSENFELD, MG. Tissue-specific regulation of retinal and pituitary precursor cell proliferation. Science, 2002, vol. 297, n. 5584, p. 1180-1183. PMid:12130660.

LINDEN, ML., HEYNEN, AJ., HASLINGER, RH. and BEAR, MF. Thalamic activity that drives visual cortical plasticity. Nature Neuroscience, 2009, vol. 12, n. 4, p. 390-392. http://dx.doi. org/10.1038/nn.2284. PMid:19252494.

MACNEIL, MA., HEUSSY, JK., DACHEUX, RF., RAVIOLA, E. and MASLAND, RH. The population of bipolar cells in the rabbit retina. The Journal of Comparative Neurology, 2004, vol. 472, n. 1, p. 73-86. http://dx.doi.org/10.1002/cne.20063. PMid:15024753.

MANDOLESI, G., MENNA, E., HARAUZOV, A., VON BARTHELD, CS., CALEO, M. and MAFFEI, L. A Role for retinal brain-derived neurotrophic factor in ocular dominance plasticity. Current Biology, 2005, vol. 15, n. 23, p. 2119-2124. http://dx.doi.org/10.1016/j. cub.2005.10.045. PMid:16332537.

MARCHIAFAVA, P.L. The toxic effect of light on retinal photoreceptors, its mechanism and the protection by endogenous indolamines. Archives Italiennes de Biologie, 2012, vol, 149, supplement 1423, p. 161-166. http://dx.doi.org/10.4449/aib.v149i4.

MASLAND, R. The neuronal organization of the retina. Neuron, 2012, vol. 76, n. 2, p. 266-280. http://dx.doi.org/10.1016/j. neuron.2012.10.002. PMid:23083731.

MASLAND, RH. Cell Populations of the retina: the proctor lecture. Investigative Ophthalmology \& Visual Science, 2011, vol. 52, n. 7, p. 4581-4591. http://dx.doi.org/10.1167/iovs.10-7083. PMid:21712414.

MCGILLEM, GS. and DACHEUX, RF. Rabbit cone bipolar cells: correlation of their morphologies with whole-cell recordings. Visual Neuroscience, 2001, vol. 18, n. 5, p. 675-685. http://dx.doi. org/10.1017/S0952523801185019. PMid:11925003.

MESCHER, A. Junqueira's basic histology: text \& atlas. 12th ed. Columbus: McGraw-Hill Education, 2005.

MOORE, KL., PERSAUD, TVN. and TORCHIA, MG. The developing human: clinically oriented embryology. Philadelphia: Saunders, 2013.

MURAOKA, Y., IKEDA, HO., NAKANO, N., HANGAI, M., TODA, Y., OKAMOTO-FURUTA, K., KOHDA, H., KONDO, M., TERASAKI, H., KAKIZUKA, A. and YOSHIMURA, N. Real-time imaging of rabbit retina with retinal degeneration by using spectraldomain optical coherence tomography. PLoS One, 2012, vol. 7, n. 4, p. e36135. http://dx.doi.org/10.1371/journal.pone.0036135. PMid:22558356.

OKANO, K., MAEDA, A., CHEN, Y., CHAUHAN, V., TANG, J., PALCZEWSKA, G., SAKAI, T., TSUNEOKA, H., PALCZEWSKI, $\mathrm{K}$. and MAEDA, T. Retinal cone and rod photoreceptor cells exhibit differential susceptibility to light-induced damage. Journal of Neurochemistry, 2012, vol. 121, n. 1, p. 146-156. http://dx.doi. org/10.1111/j.1471-4159.2012.07647.x. PMid:22220722.

ORGANISCIAK, DT. and VAUGHAN, DK. Retinal light damage: mechanisms and protection. Progress in Retinal and Eye Research, 2010, vol. 29, n. 2, p. 113-134. http://dx.doi.org/10.1016/j. preteyeres.2009.11.004. PMid:19951742.

PEREZ, M-TR. and CAMINOS, E. Expression of brain-derived neurotrophic factor and of its functional receptor in neonatal and adult rat retina. Neuroscience Letters, 1995, vol. 183, n. 1-2, p. 96-99. http://dx.doi.org/10.1016/0304-3940(94)11123-Z. PMid:7746496.

SAKPAL, TV. Sample size estimation in clinical trial. Perspectives in Clinical Research, 2010, vol. 1, n. 2, p. 67-69. PMid:21829786.

SCHINDELIN, J., ARGANDA-CARRERAS, I., FRISE, E., KAYNIG, V., LONGAIR, M., PIETZSCH, T., PREIBISCH, S., RUEDEN, C., SAALFELD, S., SCHMID, B., TINEVEZ, J-Y., WHITE, DJ., HARTENSTEIN, V., ELICEIRI, K., TOMANCAK, P. and 
CARDONA, A. Fiji: an open-source platform for biological-image analysis. Nature Methods, 2012, vol. 9, n. 7, p. 676-682. http:// dx.doi.org/10.1038/nmeth.2019. PMid:22743772.

SCHWEMER, J. Renewal of visual pigment in photoreceptors of the blowfly. Journal of Comparative Physiology A, Neuroethology, Sensory, Neural, and Behavioral Physiology, 1984, vol. 154, n. 4, p. 535-547. http://dx.doi.org/10.1007/BF00610167.

SEKI, M., NAWA, H., FUKUCHI, T., ABE, H. and TAKEI, N. $\mathrm{BDNF}$ is upregulated by postnatal development and visual experience: quantitative and immunohistochemical analyses of BDNF in the rat retina. Investigative Ophthalmology o Visual Science, 2003, vol. 44, n. 7, p. 3211-3218. http://dx.doi.org/10.1167/iovs.02-1089. PMid:12824273.

STRETTOI, E., DACHEUX, RF. and RAVIOLA, E. Cone bipolar cells as interneurons in the rod pathway of the rabbit retina. The Journal of Comparative Neurology, 1994, vol. 347, n. 1, p. 139-149. http:// dx.doi.org/10.1002/cne.903470111. PMid:7798378.

SURESH, K. and CHANDRASHEKARA, S. Sample size estimation and power analysis for clinical research studies. Journal of Human Reproductive Sciences, 2012, vol. 5, n. 1, p. 7-13. http://dx.doi. org/10.4103/0974-1208.97779. PMid:22870008.

SYKA, J. Plastic changes in the central auditory system after hearing loss, restoration of function, and during learning. Physiological Reviews, 2002, vol. 82, n. 3, p. 601-636. http://dx.doi.org/10.1152/ physrev.00002.2002. PMid:12087130.

SZUMIŃSKI, M. and BAKUNOWICZ-ŁAZARCZYK, A. Assessment of retinal ganglion cells thickness in high myopia. Klinika Oczna, 2012, vol. 114, n. 3, p. 180-183. PMid:23373397.

TERAYAMA, Y., KANEKO, Y., KAWAMOTO, K. and SAKAI, N. Ultrastructural changes of the nerve elements following disruption of the organ of Corti. I. Nerve elements in the organ of Corti. Acta Oto-Laryngologica, 1977, vol. 83, n. 1-6, p. 291-302. http://dx.doi. org/10.3109/00016487709128848. PMid:857602.

TRACHTENBERG, JT. and STRYKER, MP. Rapid anatomical plasticity of horizontal connections in the developing visual cortex. The Journal of Neuroscience, 2001, vol. 21, n. 10, p. 3476-3482. PMid:11331376.
TROPEPE, V., COLES, BL., CHIASSON, BJ., HORSFORD, DJ., ELIA, AJ., MCINNES, RR. and VAN DER KOOY, D. Retinal stem cells in the adult mammalian eye. Science, 2000, vol. 287, n. 5460, p. 2032-2036. http://dx.doi.org/10.1126/science.287.5460.2032. PMid:10720333.

VAEGAN, M. and TAYLOR, D. Critical period for deprivation amblyopia in children. Transactions of the Ophthalmological Societies of the United Kingdom, 1979, vol. 99, n. 3, p. 432-439. PMid:298827.

VECINO, E., CAMINOS, E., UGARTE, M., MARTÍN-ZANCA, D. and OSBORNE, NN. Immunohistochemical distribution of neurotrophins and their receptors in the rat retina and the effects of ischemia and reperfusion. General Pharmacology, 1998, vol. 30, n. 3, p. 305-314. http://dx.doi.org/10.1016/S0306-3623(97)00361-3. PMid:9510078.

WORLD HEALTH ORGANISATION - WHO. Visual impairment and blindness. Geneva: WHO, 2012.

ZHAO, S., TIAN, H., MA, L., YUAN, Y., YU, CR. and MA, M. Activity-dependent modulation of odorant receptor gene expression in the mouse olfactory epithelium. PLoS One, 2013, vol. 8, n. 7, p. e69862. http://dx.doi.org/10.1371/journal.pone.0069862. PMid:23922828.

ZHAO, Z. and JIANG, C. Effect of myopia on ganglion cell complex and peripapillary retinal nerve fibre layer measurements: a Fourierdomain optical coherence tomography study of young Chinese persons. Clinical es Experimental Ophthalmology, 2013, vol. 41, n. 6, p. 561566. http://dx.doi.org/10.1111/ceo.12045. PMid:23231592.

ZHOU, X., AN, J., WU, X., LU, R., HUANG, Q., XIE, R., JIANG, L. and QU, J. Relative axial myopia induced by prolonged light exposure in C57BL/6 mice. Photochemistry and Photobiology, 2010, vol. 86, n. 1, p. 131-137. http://dx.doi.org/10.1111/j.17511097.2009.00637.x. PMid:19912561.

Received June 7, 2014 Accepted November 16, 2015 